4. Kuranova, S. I. (2012) Osnovi psikholingvistiki [Fundamentals of psycholinguistics]. Kyiv, 208 p. [in Ukrainian].

5. Pasichnyk, Ye. A. (2000). Metodyka vykladannia ukrainskoi literatury $v$ serednikh navchalnykh zakladakh [Methods of Teaching Ukrainian Literature at Secondary Educational Establishments]. Kyiv, 384 p. [in Ukrainian].

6. Sent-Ekziuperi, A. (2015). Malenkyi prynts. Le Petit Prince [The Little Prince]. Kharkiv, 160 p. [in France].

7. Sirotenko, V. \& Bondarenko, O. (2018) Osoblivosti provedennya praktichnih zanyat pri vivchenni integratsiynogo kursu "Dityacha literatura z metodikoyu navchannya 1Iteraturnogo chitannya" [Features of Practical Classes in Studying the Integration Course
"Children's Literature with the Methods of Literary Reading"]. "Profesionalizm pedagoga: teoretichni $i$ metodichni aspekti". Electronic scientific journal. Sloviansk. Vol. 7. pp. 137 - 149. DOI https://doi.org/ 10.31865/2414-9292.7.2018.140591. [in Ukrainian].

8. Umberto, E. (2005). Rol chitatelia. Issledovaniia po semiotike teksta [The Role of the Reader: Explorations in the Semiotics of Texts]. Saint-Petersburg, 502 p. [in Russian].

9. Chepeleva, N.V. (2015). Tekst i chitach [Text and reader]. Zhitomir, 124 p. [in Ukrainian].

10. Chernyavskaya, V. Ye. (2009). Lingvistika teksta: Polikodovost, intertekstualnost, interdiskursivnost [Text Linguistics: Polycodedness, intertextuality, interdiscursiveness]. Moscov, 248 p. [in Russian].

Стаття надійшла до редакції 22.07.2019

УДК 371.132: 316.422

DOI:

Володимир Ковальчук, доктор педагогічних наук, професор, завідувач кафедри математики, інформатики та методики їх викладання у початковій школі Дрогобицького державного педагогічного університету імені Івана Франка

\title{
МОДЕРНІЗАЦІЯ СУЧАСНОЇ ПЕДАГОГІЧНОЇ ОСВІТИ: СВІТОГЛЯДНІ АСПЕКТИ
}

Автор статті розглядає актуальні проблеми модернізачії вітчизняної педагогічної освіти; визначає основні напрями подолання кризових явищ в освіті, необхідність семантичних та аксіологічних трансформацій у свідомості сучасного спеціаліста і вчителя зокрема. У ряді випадків існуюча практика розвитку педагогічної освіти не відповідає вимогам сучасного інформаційного й техногенного суспільства, а тому не може забезпечити своєчасну й адекватну підготовку молодих людей до майбутнього. На думку автора, не менш важливим аспектом модернізації освіти виступає вплив ї̈ на розвиток демократичних засад у суспільному житті.

Ключові слова: модернізація; світогляд; освітня політика; соціалізація; культура.

Jim. 5.

Volodymyr Kovalchuk, Doctor of Sciences (Pedagogy), Professor, Head of the Mathematics, Informatics and Methods of Teaching them at Elementary School Department Drohobych Ivan Franko State Pedagogical University

\section{MODERNIZATION OF MODERN PEDAGOGICAL EDUCATION: WORLDWIDE ASPECTS}

The author considers the actual problems of modernization of the national pedagogical education; defines the main directions of overcoming crisis phenomena in education, the need for semantic and axiological transformations in the consciousness of modern specialist and teacher in particular. According to the author's opinion, a very important aspect of the modernization of education is its impact on the development of democratic principles in public life. In some cases, the current practice of developing pedagogical education does not meet the requirements of modern information and technogenic society, and therefore cannot provide timely and adequate preparation of young people for the future. Also, a number of contradictions, which are inherent to the problem of the modernization of pedagogical education in the conditions of the crisis of education, which has become planetary scale, has been carried out. Significant divergence of views on the existing and inevitable processes of transformation and modernization of pedagogical education is noted. The reasons and factors influencing the development of the present stage of development of the national pedagogical education, adjusting the existing definitions, are determined. The analysis of functional disorders of the education system is given, the causes of their emergence and ways of their overcoming are given, as well as the notion of pedagogical problem is defined.

Thus, the analysis carried out by the author testifies to the essential difference between the conditions of occurrence and the conditions of solving the problems of the pedagogical education in time-the first ones precede the second. The main factors contributing to overcome the pedagogical problem are also identified. It is also 


\section{МОДЕРНІЗАЦЯ СУЧАСНОЇ ПЕДАГОГІЧНОЇ ОСВІТИ: СВІТОГЛЯДНІ АСПЕКТИ}

important to generalize that the ideology for the modernization of pedagogical education is the choice of a semantic filter for the arrangement of the form and mechanism of the implementation of the content of education into the structure of the personality.

Keywords: modernization; worldview; an educational policy; socialization; a culture.

П остановка проблеми. Україна, як невід'ємна складова світової спільноти, зазнає відповідних змін і новацій. Відтак, ми стаємо свідками створення глобального світопорядку, в умовах якого інформація, наука й освіта задають темпоритм саморозгортання та сталість функціонування нового типу соціальних відносин. Зважаючи на складність проблем майбутнього етапу суспільного розвитку, виникає нагальна потреба в якісно новій особистості, яка б володіла значно вищим інтелектуальним та життєвоенергетичним потенціалом, ніж представники попереднього покоління людей [2]. Зрозуміло, що за цих умов перед педагогічною освітою української держави постає проблема забезпечення iї адекватності науково-технічному та освітянському процесам, що детермінують іiі стан, напрямок та темпи розвитку. Замовчувати проблему неадекватності стану освітянської галузі вимогам інформаційної цивілізації неможливо з якихось політичних чи ідеологічних мотивів. 3 огляду на це нині перед вітчизняною педагогічною освітою постає проблема вироблення моделі, яка б адекватно відповідала сучасному науково-технічному поступу, що детермінує їі стан, напрямок і темпи розвитку.

Аналіз наукових досліджень. Виробленню моделі модернізації педагогічної освіти певним чином сприяли дослідження багатьох вітчизняних науковців і практиків. Суттєвий внесок у такого роду дослідження, а особливо у дослідження світоглядно-методологічного підгрунтя трансформації вітчизняної освіти зробили В.П. Андрущенко, О.С. Анісімов, Г.О. Балл, В.П. Бех, І.А. Зязюн, М.С. Коган, В.О. Кудін, М.І. Михальченко, І.П. Підласий та інші. Хоча заради об'єктивності слід зазначити, що вітчизняні фахівці-освітяни досить часто припускаються однобічності у своїх оцінках і висновках і до того ж застосовують не автентичні поняття і тлумачення.

Маючи на увазі рівень актуальності проблеми модернізації педагогічної освіти, автор статті мету свого доробку вбачає в уточненні власне змісту предмету педагогіки; а також у визначенні сутності і категоріального змісту поняття "модернізація".

Виклад основного матеріалу. Освітня політика, яку проводять в Україні, і яка спирається на поглиблення реформ в освіті, на модифікацію і плюралізм підходів до цієї складної і життєво невідкладної роботи, знаходить підтримку серед прогресивної частини нашого суспільства. Освіта починає усвідомлюватися суспільством як найважливіший фактор не лише технологічного та соціально-економічного розвитку, а й як запорука виживання цивілізації, як умова подолання глобальних екологічної та духовної криз.

Вважаю за потрібне зазначити, що для розгляду специфіки умов вирішення проблем модернізації педагогічної освіти, треба мати на увазі два моменти: по-перше, провести більш глибоку лінію між умовами виникнення та умовами вирішення педагогічних проблем; подруге, уточнити світоглядно-методологічні та ідеологічні передумови їх вирішення. У той же час слід зважити на те, що багато дослідників від Джона Дьюї до Ліпсета і Сидні Верба розглядали освіту як базову передумову демократії. I новітні соціологічно-психологічні дослідження свідчать про те, що освіта виступає найбільш важливою змінною величиною у формуванні сучасної людини, оскільки саме поняття “сучасна людина" може означати одне суттєве, - це людина, яка $є$ інформованим громадянином, яка бере участь у житті суспільства, керуючись при цьому почуттям особистої відповідальності.

Можна впевнено стверджувати, що освіта може вплинути на демократію двома способами. У першому випадку освіта прямо впливає на демократизацію суспільства через вплив сукупності освічених громадян, здатних впливати на політичні процеси й інститути. У другому випадку підвищення рівня освіти впливає опосередковано на демократію через підвищення рівню матеріальних статків людей. І останнє вельми наглядно демонструє новітня історія. Після другої світової війни вплив освіти на економічний розвиток і зростання доходів населення беззаперечний у країнах, що впевнено рухались по шляху демократії. Швидке економічне зростання без добре освіченої робочої сили було б просто неможливим. А відтак, для всієї системи вітчизняної освіти в останні роки характерне приниження значення і ролі професійної освіти робітників. Власне це і не заперечують високопосадовці освіти. У нас робітників і досі вчать значно швидше і значно поверховіше ніж у постіндустріальних країнах.

Таким чином, говорячи про модернізацію педагогічної освіти як соціальну проблему, слід 
зазначити, що вона принципово відрізняється від визначення соціального завдання саме зважаючи на рівень демократизації суспільства. Різниця полягає у тому, що для вирішення проблеми ще не має засобів, і цим вона якісно відрізняється від завдання, для вирішення якого завжди є засоби [1]. Скажімо, досить подивитись на те, як корелює освітній стаж із рівнем демократії і як це впливає на рівень доходів людей. Хоча освіта є основним чинником підвищення доходів, що швидше беззаперечно, тим не менше ця кореляція не абсолютна.

В Україні ситуація з кількістю викладацьких кадрів статистично краща, адже за роки незалежності розширили свій професорськовикладацький склад більшість державних закладів, а також з'явилась доволі велика кількість недержавних освітніх закладів [5]. Втім, в Україні більшою мірою це стосується вищої школи, тоді як у середній, і особливо сільській школі, ситуація з кількістю викладацьких кадрів (вчителів) значно тривожніша. Особливо тривожною є ситуація 3 якістю викладацького складу в системі освіти. І не лише в Україні. Адже, якщо кількість викладачів у розвинених країнах не збільшилась, то вимоги до них значно зросли. Особливо багато залежить від професійного та світоглядно-методологічного рівня вчителів і викладачів у країнах, що поставили перед собою завдання інтенсивної модернізації суспільства. До таких країн належить і Україна.

В деяких країнах, наприклад у США, частка адміністративного та допоміжного персоналу у системі освіти складає понад 50\% (для порівняння у Греції - менше 5\%) [6, 276]. Очевидно, це свідчить про велике значення процесів управління освітою і самоосвітою в деяких країнах.

Важливим покажчиком є співвідношення тих, що навчаються, до тих, хто навчає. У країнах, які входять до Організації економічного співробітництва і розвитку (ОЕСР), відмінності по цьому покажчику доволі значні $[6,119]$. В державних початкових школах країн ОЕСР число учнів на одного вчителя коливається від 31,7 у Республіці Корея до 9,5 у Норвегії. В державних середніх школах це співвідношення коливається від 23,7 в Кореї та Туреччині до 6,9 у Фламандській громаді Бельгії. Мірою підвищення рівня освіти збільшується кількість викладачів порівняно з кількістю учнів. У середньому по країнам ОЕСР співвідношення “учні-викладачі” зменшилось 3 18,2 на початковому рівні до 16,2 на першому ступені середньої освіти і до 13,5 на другому ступені середньої освіти.
У цьому контексті можна сказати навіть більше, оскільки єдність і боротьба особистості та суспільства або індивідуального та колективного виступає як головна суперечність соціального світу, що об'єктивно визначає характер та напрямки еволюції національної системи освіти та її педагогічної складової.

Отже, розмірковуючи над проблемами модернізації педагогічної освіти, слід зазначити, що найкращим засобом стимулювання демократичного підйому у вітчизняному соціумі, який конче необхідний, $\epsilon$ прискорення економічного розвитку (це приведе до більш задовільного матеріального стимулювання праці вчителя) і реальне підвищення освітнього рівня. Протиріччя типу “старе - нове” - це протиріччя поступального розвитку, протиріччя росту. Їх вирішення означає виникнення нових можливостей, нових стимулів та рушійних сил у галузі педагогічної освіти. Однак, перш ніж демократичні інститути зможуть зміцнитись, люди повинні їх засвоїти, знайти досвід користування ними. А тому при пошуку джерел подальшого розвитку педагогічної системи слід мати на увазі цю складну діалектику сьогодення.

Важливу роль у процесах модернізації освіти може відігравати й багате громадянське життя, бо саме через стимуляцію активної участі громадян у суспільно-політичному житті підвищується політична дієвість і освіта демократичних громадян.

Вищевикладений підхід вимагає більш уважніше розглянути систему освіти саме як складову частину соціального організму країни, який $є$ таким соціальним цілим, що обумовлює розвиток системи освіти взагалі і педагогічної освіти зокрема. На наш погляд, соціальний організм країни є складним утворенням особистості й соціуму, який виник на мікрорівні завдяки здатності соціального світу до самоорганізації та подальшої еволюції в залежності від рівня зрілості людини та зміни зовнішнього середовища. Тому соціальний організм на макрорівні постає як органічна єдність особистості й суспільства, суб'єктивних і об'єктивних суспільних відносин у момент їхньої діалектичної взаємодії між собою $[3,36]$.

Тут необхідно сказати навіть більше - єдність і боротьба особистості та суспільства або індивідуального та колективного, є головним протиріччям соціального світу, яке об'єктивно визначає характер та напрямки еволюції національної системи освіти та їі педагогічної складової.

Звідси цілком стає зрозумілим, чому освіта 
використовується як захист проти сил, що “знеособлюють” людину в демократичному суспільстві, і чому в кризовому суспільстві завжди загострюється питання смислу життя як для окремих людей, так і для всього суспільства в цілому. Саме з цього приводу І.А.Зязюн слушно зауважує, що проблеми духовного розвитку людини сьогодні, по суті, стали обов'язковою умовою виживання суспільства. Усі наші сучасні біди мають, як правило, одну причину - дефіцит культури і моральності, дефіцит доброти і милосердя, краси людських стосунків [2, 21].

Наступним кроком, тобто після встановлення субстанціональної єдності національної системи освіти з соціальним організмом країни та світу, $є$ вибір ідеології вирішення проблем модернізації педагогічної освіти в Україні. При цьому зазначимо, що під ідеологією тут треба розглядати сукупність ідей (семантичних фільтрів), на основі яких ми налаштовані переосмислити місце та роль педагогічної теорії та практики у розбудові української державності [4]. Стан справ у вітчизняній філософській думці ускладнюється тим, що сьогодні на ідеологічному обрії немає жодної ідеології, яка б прогресувала. На жаль, відсутня чітко сформульована ідеологія державного будівництва в Україні. Тому ми поки що не маємо ідеальної моделі національної системи освіти, середньої та вищої школи, не можемо визначитись з іï характером.

Ідеологія для модернізації педагогічної освіти полягає у виборі семантичного фільтру для упорядкування форми та механізму подання змісту освіти в структуру особистості. Якщо тут діяти за аналогією, то оскільки за часи індустріального етапу розвитку провідною ідеологемою була політехнічна освіта, то в умовах переходу України до інформаційної фази розвитку має бути нова ідеологема, а саме індивідуалізація або особистісно орієнтована парадигма освіти. Відповідно до цього педагогічна наука повинна теж набути певного змісту та специфічної форми.

Висновки. Таким чином, проведений автором аналіз свідчить про суттєву відмінність умов виникнення та умов вирішення проблем педагогічної освіти у часі - перші передують другим. Визначено також основні чинники, які сприяють подоланню педагогічної проблеми. Для сучасної педагогічної освіти важливо також готувати особистість до життєдіяльності в умовах нового провідного чинника, а саме - поділу інформаційної праці. Тому для педагогічної науки головним детермінантом стає смислогенез, а не опрацюванням матеріальних факторів. Ось чому освіту слід розглядати чинник, що сприяє вкоріненню людини в культурне оточення, що має значну історію свого розвитку.

Перспективи подальших досліджень:

- дослідження соціальних чинників трансформації освіти;

- дослідження впливу економіко-політичних змін у суспільстві на подальший розвиток освіти; - дослідження освітньої політики країн СС.

\section{ЛІТЕРАТУРА}

1. Генрі С. Роуен. Підводні течії “третьої хвилі”. Глобальне відродження демократії. Львів, 2014. С. 374-388.

2. Зязюн І.А. Концептуальні засади теорії освіти в Україні. Педагогіка і психологія професійної освіти. 2000. №1. С.12-13.

3. Кушерець В. Система освіти в ноосферному вимірі. Потреба світоглядної та методологічної переорієнтації. Вищза освіти Украӥни. 2003. № 3. С. $36-40$.

4. Лутай В.С. Філософія сучасної освіти. Київ, $1996.256 \mathrm{c}$.

5. Педагогічні технології у неперервній професійній освіті: монографія/За ред. С.О. Сисоєвої. Київ, 2011. 156 с.

6. Education at a Glance OECD 1997, 443 p.

\section{REFERENCES}

1. Rouen, S.Henri (2014). Pidvodni techii “"tretoi khvyli" [Underwater currents of the "third wave"]. Global revival of democracy. Lviv. pp. 374-388. [in Ukrainian].

2. Ziaziun, I. (2000). Kontseptualni zasady teorii osvity v Ukraini [Conceptual foundations of the theory of education in Ukraine]. Pedagogy and psychology of vocational education. No.1. pp. 1213. [in Ukrainian].

3. Kusherets, V. (2003). Systema osvity v noosfernomu vymiri. Potreba svitohliadnoi ta metodolohichnoi pereoriientatsii [Educational system in the noosphere dimension. The need for ideological and methodological reorientation]. Higher education in Ukraine. No. 3. pp. 36-40. [in Ukrainian].

4. Lutai, V. (1996). Filosofiia suchasnoi osvity [Philosophy of modern education]. Kyiv, 256 p. [in Ukrainian].

5. Sysoieva, S. (2011). Pedahohichni tekhnolohii u neperervnii profesiinii osviti: monohrafiia [Pedagogical technologies in continuous vocational education: monograph]. Kyiv, 156 p. [in Ukrainian].

6. Education at a Glance OECD 1997, 443 p. [in English].

Стаття надійшла до редакції 08.07.2019 